\title{
Effect of metal layer stacking order on the growth of $\mathrm{Cu}_{2} \mathrm{ZnSnS}_{4}$ thin films
}

Narayana Thota $^{\mathrm{a}}$, M. GuruBhasker ${ }^{\mathrm{a}}$, M. Anantha Sunil ${ }^{\mathrm{b}}$ P. Prathap ${ }^{\mathrm{c}}$, Y.P. Venkata Subbaiah ${ }^{\mathrm{a}, \mathrm{d} *}$, Ashutosh Tiwari $^{\mathrm{d}}$

${ }^{a}$ Advanced Materials Research Laboratory, Department of Physics, Yogi Vemana University, Kadapa, A.P., 516003 , India

${ }^{b}$ Department of Instrumentation and Applied Physics, Indian Institute of Sciences, Bangalore 560012, India

${ }^{c}$ National Physical laboratory, K. S. Krishnan Road, New Delhi 110012, India

${ }^{d}$ Nanostructured Materials Research Laboratory, Department of Materials Science and Engineering, University of Utah, Salt lake city, Utah 84112,USA

\section{Abstract}

In this paper we have presented an in-depth study of effect of metallic precursor stacking order on the growth of the $\mathrm{Cu}_{2} \mathrm{ZnSnS}_{4}$ (CZTS) thin films. The CZTS films were prepared by employing a two-step process comprising of sequential sputtering of the metal precursors followed by sulfurization. An optimized stacking sequence as well as growth mechanism for obtaining the single phase CZTS has been proposed based on the results of XRD, Raman, XPS, $\mathrm{UV}-\mathrm{V}$ is and electrical studies. A combination of Raman analysis and XPS has been carried out to confirm the CZTS phase formation and to detect any minor phases, if present. The occurrence of Raman modes at around 286 and $336 \mathrm{~cm}^{-1}$ for the $\mathrm{Zn} / \mathrm{Cu} / \mathrm{Sn} / \mathrm{Cu}$ stack sulfurized at $500{ }^{\circ} \mathrm{C}$ indicated the existence of prominent Kesterite CZTS phase. The perfect homogeneous mixing of sequential precursors together with the elemental sulfur was observed in the case of sulfurized stack order of $\mathrm{Zn} / \mathrm{Cu} / \mathrm{Sn} / \mathrm{Cu}$, and which yielded single phase CZTS films, which and further confirmed by high resolution core level XPS measurements. Stack dependent micro structural features and elemental analysis were also carried out using FESEM attached to EDS. The p-type charge carriers as detected using hot-probe measurement technique and the band-gap energy of $\sim 1.52 \mathrm{eV}$ as estimated from the absorbance spectrum, suggested that the $\mathrm{Zn} / \mathrm{Cu} / \mathrm{Sn} / \mathrm{Cu}$ stack order is most appropriate for realizing single phase CZTS growth using two step method.

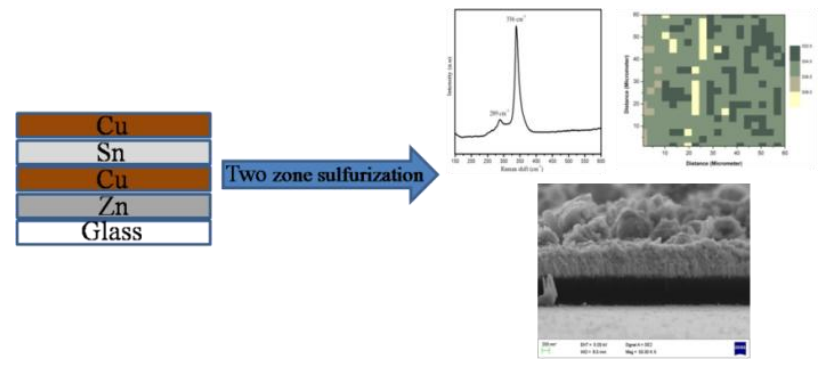

Keywords: $\mathrm{Cu}_{2} \mathrm{ZnSnS}_{4}$ thin films, two step growth, sulfurization, Raman mapping, $\mathrm{x}$-ray photo electron spectroscopy

*Corresponding author: subbaiahy@gmail.com 


\section{Introduction}

The apprehensions of high cost and, involvement of rare as well as toxic elements associated with current photovoltaic technologies have motivated the researchers to explore low cost and non-toxic materials based newer technologies for designing the cost-efficient and ecofriendly photovoltaic (PV) cells. A variety of new and low-cost photovoltaic technologies have emerged recently based on dye sensitized solar cells (DSSCs), organic polymer bulk heterojunctions and organic-inorganic hybrid perovskites, but, these technologies are still in the proof-of-concept stage and many of these face quite severe stability issues [1-5]. As a result even today, the major share of PV market is captured by inorganic semiconductors based technologies, specifically wafer based crystalline Si technology [6]. Alternative to Si technology, the thin film $\mathrm{CdTe}$ and $\mathrm{Cu}(\mathrm{In}, \mathrm{Ga}) \mathrm{Se}_{2}$ (CIGS) technologies are found to be cheaper and equally efficient [7] and have currently reached production volumes of > 1GW/yr [8]. However, to meet the world's multi terawatt energy demand in the future, the cost and scarcity of 'In' and 'Te' as well as the toxicity of ' $\mathrm{Cd}$ ' will become a major barrier may be an impediment for CdTe and CIGS based technologies. In this context, the earth abundant and non-toxic compound semiconductors such as $\mathrm{Cu}_{2} \mathrm{ZnSnS}_{4}$ (CZTS), $\mathrm{Cu}_{2} \mathrm{SnS}_{3}$ (CTS) and $\mathrm{SnS}$ have been extensively studied. Among them, CZTS has received partieular interest greater attention and show rapid improments proved to be more effective in terms of highest conversion efficiency, $9.2 \%$ [813], which indicates its potentiality as a low-cost absorber for PV application. Although the achieved efficiencies are quite encouraging, they are still far behind from predicted theoretical efficiency for CZTS (31\%) as per Shockly-Queisser limit [14] and also from the efficiencies of earlier counterparts (CIGS and CdTe) [7] suggesting a need for further in depth keener studies on the growth and fundamental properties of the CZTS.

A variety of physical and chemical synthesis techniques have been used to prepare CZTS films in the past [9, 15-20]. Majority of these techniques involved two steps: first, low temperature deposition of metallic precursor, either simultaneously i.e. co deposition or sequentially i.e. sequential deposition followed by high temperature sulfurization to induce homogeneous mixing of all the elements and subsequent recrystallization that finally leads to poly-crystalline grain growth of CZTS. The sequential metal deposition is preferred father than to co-deposition, as one can precisely control the composition of the final film by adjusting 
individual precursor layer thicknesses. The precise control of individual metal thickness and its composition to the desired ratio is very important during the CZTS growth to obtain better photovoltaic performances. For example, CZTS devices developed from slightly offstoichiometric metallic ratios have shown much better efficiency than those devices developed from stoichiometric metal ratios. More specifically, the CZTS films grown with $\mathrm{Cu}$-poor $(\mathrm{Cu} /(\mathrm{Zn}+\mathrm{Sn}) \sim 0.8)$ and Zinc-rich $(\mathrm{Zn} / \mathrm{Sn} \sim 1.2)$ metal compositions have shown better efficiencies $[10,11,21]$. It is widely published in literature that copper compounds such as $\mathrm{Cu}_{2-}$ ${ }_{x} \mathrm{~S}$ and $\mathrm{Cu}_{2} \mathrm{SnS}_{3}$ are easily formed alongside CZTS in case of $\mathrm{Cu}$-rich or Cu-optimum compositions [11, 22]. The presence of these phases is very harmful due to their high conductivities that can cause shunting paths or additional recombination processes in the final device and thereby result in significant drop in $\mathrm{V}_{\mathrm{oc}}$. Even, having Moreover, presence of $\mathrm{Zn}$ rich composition could often lead to a $\mathrm{ZnS}$ phase, however, its presence is not harmful unlike that of $\mathrm{Cu}$-compounds [22]. Hence, Cu-poor and Zn-rich compositions in CZTS films are highly recommended for avoiding the detrimental copper-sulfide phases for extracting best efficiencies. Earlier studies have shown that in two step processes, even if precursor metallic layers are deposited with desired ratios, after high temperature annealing (sulfurization) step there occurs drastic variations in composition, which are mainly stack order dependent $[23,24]$. In order to overcome the above problem, in the present study we have performed in-depth investigations on the growth of the CZTS films with all possible combinations of metallic stacks and their impact on the material properties.

\section{Experimental section}

\subsection{CZTS film Preparation}

CZTS thin films were prepared by a two-step growth process of sulfurization of sputtered metallic stack precursors. A detailed description of metallic stacks deposition is reported elsewhere [25]. To study the stacking order influence on the properties of CZTS films, all possible combinations of stacks were prepared while keeping other deposition conditions unchanged. Seven kinds of stacks were categorized into Sn-capped, Zn-capped and Cu-capped stacks depending upon whether the top layer of the given stack was $\mathrm{Sn}(\mathrm{Cu} / \mathrm{Zn} / \mathrm{Sn}, \mathrm{Zn} / \mathrm{Cu} / \mathrm{Sn})$ or $\mathrm{Zn}(\mathrm{Sn} / \mathrm{Cu} / \mathrm{Zn}, \mathrm{Cu} / \mathrm{Sn} / \mathrm{Zn})$, or $\mathrm{Cu}(\mathrm{Sn} / \mathrm{Zn} / \mathrm{Cu}, \mathrm{Zn} / \mathrm{Sn} / \mathrm{Cu}, \mathrm{Zn} / \mathrm{Cu} / \mathrm{Sn} / \mathrm{Cu})$, respectively. The stack order representation used in the present manuscript can be understood as bottom layer/middle layer/top layer and is shown in Fig.1. The total thickness of each stack was maintained at 
approximately $300 \mathrm{~nm}$ by controlling the sputter time such that the metal ratios are close to the best reported compositions ( $\mathrm{Cu}-$ poor and $\mathrm{Zn}$ - rich) for high efficiency $\mathrm{CZTS}$ solar cells. The sputter time for the deposition of $\mathrm{Cu}, \mathrm{Zn}$ and $\mathrm{Sn}$ were fixed at 30, 22 and $15 \mathrm{~min}$. to achieve $130 \mathrm{~nm}, \sim 90 \mathrm{~nm}$ and $\sim 80 \mathrm{~nm}$ thicknesses, respectively. In the case of Cu-capped stacks $(\mathrm{Zn} / \mathrm{Cu} / \mathrm{Sn} / \mathrm{Cu})$, the total sputter time for $\mathrm{Cu}$ remains unchanged but is equally divided between two $\mathrm{Cu}$ layers. The subsequent sulfurization step was performed using a quartz tube set-up with an optimized $[25,26]$ sulfurization temperature of $500{ }^{\circ} \mathrm{C}$ to understand the influence of the stacking order during the growth of the CZTS.
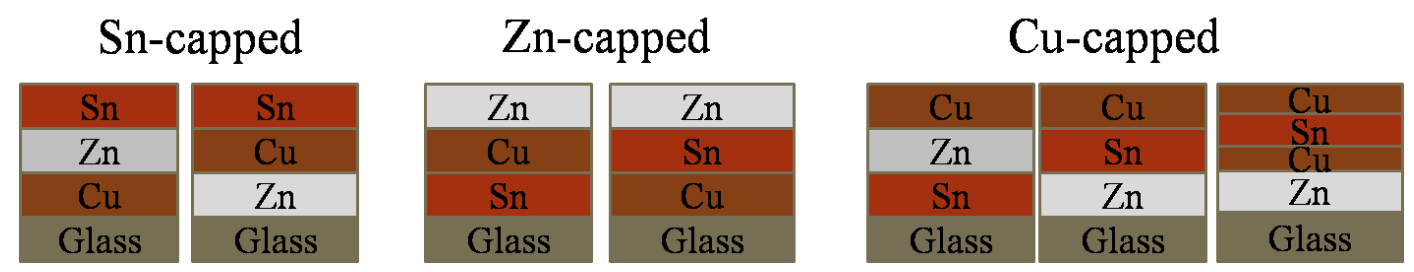

Fig.1. Schematic representation of Sn-capped, $\mathrm{Zn}$-capped and $\mathrm{Cu}$-capped stack orders

\subsection{Characterization}

The energy dispersive spectroscopic (EDS) measurements and field effect scanning electron microscope (FESEM) overhead and cross-sectional micrographs were obtained using Quanta 200 Zeiss Supra 55 system. The X-ray diffractograms were recorded using a Rigaku Smart Lab diffractometer. The data was obtained at room temperature using a $\mathrm{Cu} \mathrm{K}_{\alpha}$ radiation source in the $2 \theta$ range from 15 to $80^{\circ}$ and with a step size $0.01^{\circ}$. The Raman data mapping was performed using a WITec (Alpha 300S) scanning near field optical microscope (SNOM). The absorbance spectra were recorded using Perkin Elmer Lambda 750 UV-Vis-NIR spectrophotometer over the wavelength range $200-2500 \mathrm{~nm}$. The X-ray photoelectron spectroscopy (XPS) experiments were performed using a Kratos XPS Ultra DLD system to determine the oxidation states of the $\mathrm{Cu}, \mathrm{Zn}, \mathrm{Sn}$ and $\mathrm{S}$ present in the films. Electrical studies were carried out using hot probe and Hall effect setup.

\section{Results and Discussion}

\subsection{Compositional Changes during Sulfurization}


The relative compositions in all of the sputtered metallic stacks and their variations after sulfurization at $500{ }^{\circ} \mathrm{C}$ were determined at six different positions (spot area $5 \times 5 \mu \mathrm{m}^{2}$ ), and their average atomic percentage (at. \%) was reported. Before sulfurization, all of the metallic stacks irrespective of their stacking sequence showed only small variations in composition, with values near $\mathrm{Cu} \sim 45.83, \mathrm{Zn} \sim 29.76$ and $\mathrm{Sn} \sim 24.0$ and ratios of $\mathrm{Cu} / 2 \mathrm{Zn} \sim 0.76, \mathrm{Cu} / 2 \mathrm{Sn} \sim 0.95, \mathrm{Zn} / \mathrm{Sn} \sim$ 1.24 and $\mathrm{Cu} /(\mathrm{Zn}+\mathrm{Sn}) \sim 0.85$. However, high temperature sulfurization severely affected the final CZTS film composition in the form of elemental loss. These losses were stacking order dependent, specifically capping (top) layer dependent as listed in table 1. For Sn-capped stacks (Glass/Cu/Zn/Sn and Glass/Zn/Cu/Sn), the sulfurization yielded a two-fold increase in $\mathrm{Cu} / 2 \mathrm{Sn}$ ratio (i.e. from 0.95 to 1.8 ), while the $\mathrm{Zn} / \mathrm{Sn}$ ratio increased from 1.24 to 1.8 , indicating a large loss of Sn. The loss of $\mathrm{Sn}$ in CZTS for Sn-capped stacks is expected to be in the form of $\mathrm{SnS}_{2}$ and/or attributed to volatile nature of $\mathrm{Sn}$ at higher temperatures [27]. The $\mathrm{Zn}$-capped stacks were classified into case1, Glass/Sn/Cu/Zn, and case2, Glass/Cu/Sn/Zn. For case1, the $\mathrm{Cu} / 2 \mathrm{Zn}$ ratio increased to 1.37 while the $\mathrm{Zn} / \mathrm{Sn}$ ratio decreased to 0.71 , showing the loss of volatile $\mathrm{Zn}$ due to elevated vapor pressure ( $\mathrm{Zn} \sim 1 \mathrm{mbar}$ ) at $500{ }^{\circ} \mathrm{C}$ [28]. The loss of $\mathrm{Sn}$ is not observed in case 1 of the $\mathrm{Zn}$-capped films as $\mathrm{Cu}$ was the middle layer of the stack and acts as a shield to protect the volatile $\mathrm{Sn}$. In the latter case, when $\mathrm{Sn}$ is in the middle of the precursor stack, a slight increase in the metallic ratios is seen compared to casel of the Zn-capped samples, showing not only the loss of $\mathrm{Zn}$ but a small amount of $\mathrm{Sn}$ as well. The losses of $\mathrm{Sn}$ and $\mathrm{Zn}$ are in good agreement with recent work of Fairbrother et al. [29], who extensively investigated the loss dynamics of volatile $\mathrm{Sn}$ and $\mathrm{Zn}$ when the $\mathrm{Sn}$ and $\mathrm{Zn}$ were sequentially made as the top layers. When $\mathrm{Cu}$ is in the top of the stack, its non-volatility (because of low vapor pressure at $2.3 \times 10^{-11}$ mbar) results in a negligible loss of $\mathrm{Cu}$ [30]. Recent reports related to the selection for precursor stack order for single phase CZTS growth also emphasize $\mathrm{Cu}$ capping [31], since it protects the loss of volatile $\mathrm{Sn}$ and $\mathrm{Zn}$. In the case of the Cu-capped samples, we have tested an additional stack order (Glass/ $\mathrm{Zn} / \mathrm{Cu} / \mathrm{Sn} / \mathrm{Cu}$ ) with $\mathrm{Cu}$ insertion between $\mathrm{Zn}$ and $\mathrm{Sn}$ to make use of the high diffusivity of $\mathrm{Cu}$. The obtained metallic ratios for this particular stack order are the best-matched with those of un-sulfurized metallic precursor stack. 
Table 1. Elemental quantification of various precursor stack orders after sulfurization.

\begin{tabular}{|c|c|c|c|c|c|c|c|c|c|c|}
\hline Type & Stack order & $\begin{array}{l}\mathrm{Cu} \\
\text { at. \% }\end{array}$ & $\begin{array}{l}\mathrm{Zn} \\
\text { at. \% }\end{array}$ & $\begin{array}{l}\text { Sn } \\
\text { at. \% }\end{array}$ & $\begin{array}{l}\mathrm{S} \\
\text { at. \% }\end{array}$ & $\mathrm{Cu} / 2 \mathrm{Zn}$ & $\mathrm{Cu} / 2 \mathrm{Sn}$ & $\mathrm{Zn} / \mathrm{Sn}$ & $\mathrm{Cu} /(\mathrm{Zn}+\mathrm{Sn})$ & $\mathrm{S} /(\mathrm{Cu}+\mathrm{Zn}+\mathrm{Sn})$ \\
\hline \multirow{2}{*}{ Sn-capped } & $\mathrm{Cu} / \mathrm{Zn} / \mathrm{Sn}$ & 29.5 & 13.9 & 8.1 & 48.5 & 1.06 & 1.82 & 1.71 & 1.34 & 0.94 \\
\hline & $\mathrm{Zn} / \mathrm{Cu} / \mathrm{Sn}$ & 28.9 & 14.4 & 8.0 & 48.7 & 1.0 & 1.80 & 1.8 & 1.29 & 0.94 \\
\hline \multirow{2}{*}{ Zn-capped } & $\mathrm{Sn} / \mathrm{Cu} / \mathrm{Zn}$ & 27.0 & 9.8 & 13.7 & 49.5 & 1.37 & 0.98 & 0.71 & 1.14 & 0.96 \\
\hline & $\mathrm{Cu} / \mathrm{Sn} / \mathbf{Z n}$ & 29.5 & 9.6 & 11.7 & 49.2 & 1.53 & 1.26 & 0.82 & 1.38 & 0.96 \\
\hline \multirow{3}{*}{ Cu-capped } & $\mathrm{Sn} / \mathrm{Zn} / \mathrm{Cu}$ & 22.9 & 13.7 & 12.4 & 51.0 & 0.83 & 0.92 & 1.10 & 0.87 & 1.04 \\
\hline & $\mathrm{Zn} / \mathrm{Sn} / \mathrm{Cu}$ & 23.0 & 13.6 & 12.2 & 51.2 & 0.84 & 0.94 & 1.11 & 0.89 & 1.04 \\
\hline & $\mathrm{Zn} / \mathrm{Cu} / \mathrm{Sn} / \mathrm{Cu}$ & 22.2 & 14.8 & 11.8 & 51.2 & 0.75 & 0.94 & 1.25 & 0.83 & 1.04 \\
\hline
\end{tabular}

\subsection{Crystal Structure and Phase Confirmation}




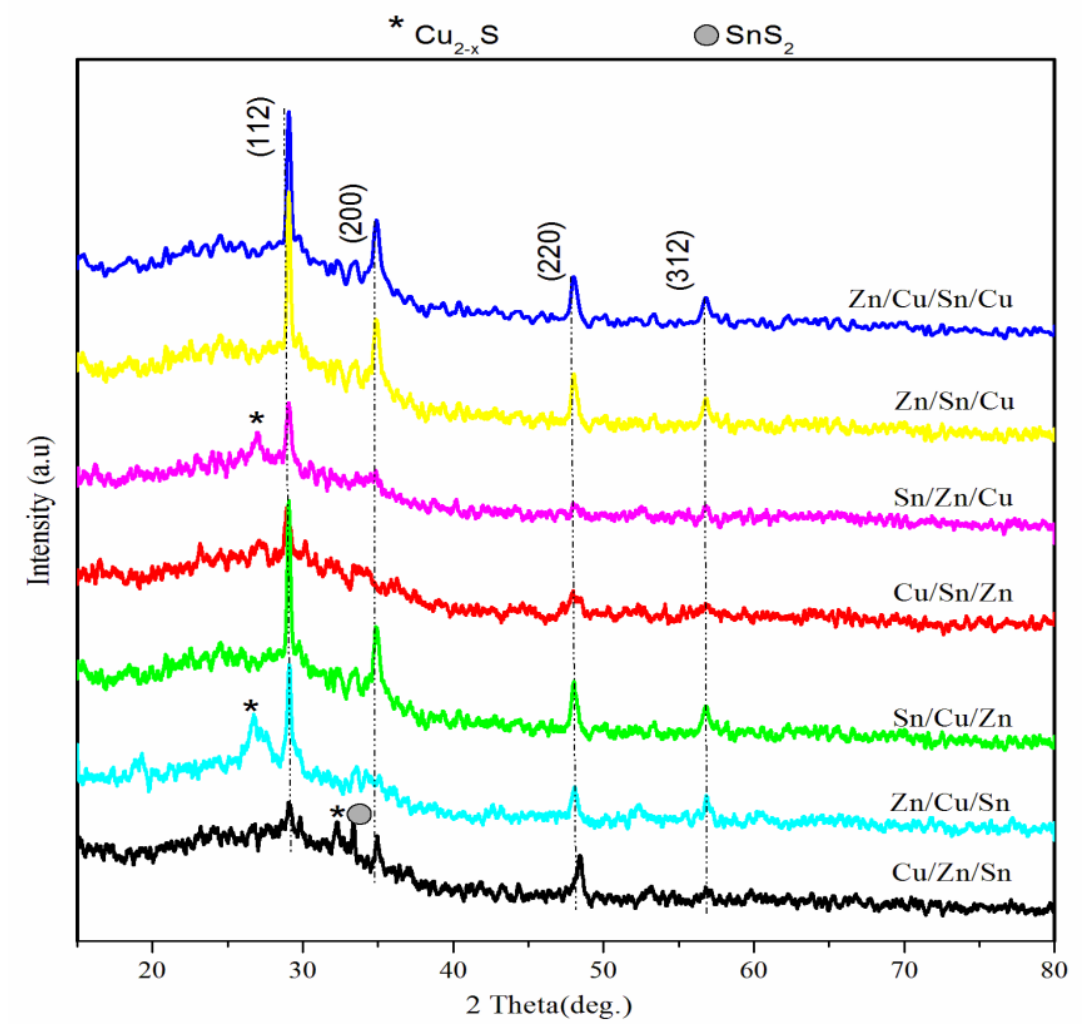

Fig.2. XRD spectra of different stack orders sulfurized at $500{ }^{\circ} \mathrm{C}$ for the growth of CZTS. 


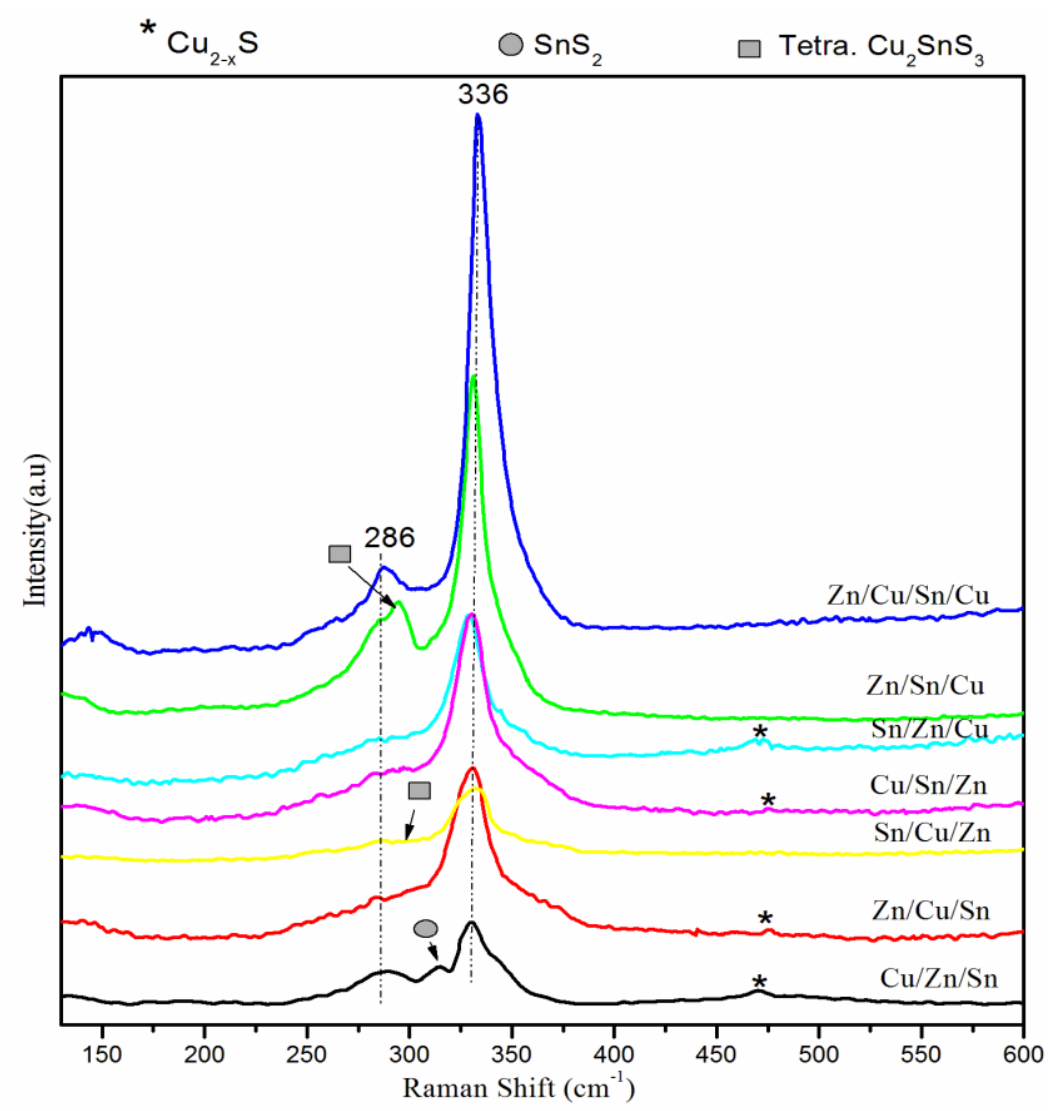

Fig.3. Raman spectra of metallic stack precursors sulfurized at $500{ }^{\circ} \mathrm{C}$.

Fig. 2 shows the XRD diffractograms of sulfurized samples corresponding to stack orders $\mathrm{Cu} / \mathrm{Zn} / \mathrm{Sn}, \mathrm{Zn} / \mathrm{Cu} / \mathrm{Sn}, \mathrm{Sn} / \mathrm{Cu} / \mathrm{Zn}, \mathrm{Cu} / \mathrm{Sn} / \mathrm{Zn}, \mathrm{Sn} / \mathrm{Zn} / \mathrm{Cu}, \mathrm{Zn} / \mathrm{Sn} / \mathrm{Cu}$, and $\mathrm{Zn} / \mathrm{Cu} / \mathrm{Sn} / \mathrm{Cu}$. All the stack orders have shown preferred orientation of (112) along with minor signature planes (200), (220) and (312) at $28.5^{\circ}, 36.0^{\circ}, 48.2^{\circ}$ and $52.8^{\circ}$, respectively, which corresponds to the kesterite phase of CZTS (JCPDS card no: 00-026-0575). Additionally, large variations in the crystallinity and few of the likely secondary phases are noticeable depending upon the stack order which are labeled with symbols in Fig. 2 and 3. The difference in crystallinity and presence of impurities can be attributed to the compositional non-uniformity as evidenced from table 1 . This is due to significant loss of $\mathrm{Sn}$ and $\mathrm{Zn}$ in case of CZTS grown using Sn-capped and Zn-capped samples respectively after high temperature sulfurization. Of all sulfurized $\mathrm{Cu}$-capped samples, the presence of $\mathrm{Cu}_{2} \mathrm{~S}$ associated with poor crystallinity in case of $\mathrm{Sn} / \mathrm{Zn} / \mathrm{Cu}$ samples was due to the lack of deep diffusion of $\mathrm{Cu}$ i.e., surface sulfurization of $\mathrm{Cu}$. The $\mathrm{Zn} / \mathrm{Sn} / \mathrm{Cu}$ has shown better crystallinity without secondary phases, however, the insertion of additional $\mathrm{Cu}$ between $\mathrm{Zn}$ and $\mathrm{Sn}(\mathrm{Zn} / \mathrm{Cu} / \mathrm{Sn} / \mathrm{Cu})$ helps in achieving best crystallinity amongst $\mathrm{Cu}$-capping stacks. However, 
distinguishing secondary phases like $\mathrm{ZnS}, \mathrm{Cu}_{2} \mathrm{SnS}_{3}$ is difficult by analyzing XRD results since their diffraction patterns and lattice constants are similar to that of the CZTS crystal system. In cases, where ambiguity remained, Raman measurements were conducted [32]. Raman measurements were performed using a $532 \mathrm{~nm}$ excitation wavelength to confirm the CZTS phase and to identify the other minor phases. Fig.3 shows the Raman spectra of all metallic stack precursors after sulfurization. All the three types of sulfurized stacking sequences have shown a strong mode at $336 \mathrm{~cm}^{-1}$ that belong to the $\mathrm{A}_{1}$ symmetry of CZTS, and it is related to pure anion modes corresponding to the vibrations of sulfur atoms surrounded by static neighboring atoms. The co-existence of a weak mode around $289 \mathrm{~cm}^{-1}$ belonging to $\mathrm{E}$ and/or B symmetry along with the $\mathrm{A}_{1}$ mode confirms the presence of CZTS in all films [33]. However, for Sn and Zn-capped stacks, a minor phase of $\mathrm{Cu}_{2-\mathrm{x}} \mathrm{S}$ is shown by the presence of a Raman active mode at $475 \mathrm{~cm}^{-1}$. The presence of this phase is due to the $\mathrm{Cu}$-richness in films stemming from the loss of $\mathrm{Sn}$ $(\mathrm{Cu} / 2 \mathrm{Sn}=1.8)$ and loss of $\mathrm{Zn}(\mathrm{Cu} / 2 \mathrm{Zn}=1.53)$ in $\mathrm{Sn}$ and $\mathrm{Zn}$-capped stacks, respectively. The appearance of another minor phase, $\mathrm{SnS}_{2}\left(314 \mathrm{~cm}^{-1}\right)$, for $\mathrm{Cu} / \mathrm{Zn} / \mathrm{Sn}$ might be expected due to the presence of a small amount of unreacted $\mathrm{SnS}_{2}$ in the form of a precipitate due to $\mathrm{Sn}$ being the top layer. The presence of the $\mathrm{ZnS}$ (275 and $352 \mathrm{~cm}^{-1}$ ) phase [34] could not be completely ruled out, particularly in Zn-capped stacks as $\mathrm{Zn}$ was top layer, but its identification requires a UV excitation $(\sim 325 \mathrm{~nm})$ source [32].

The sulfurization of $\mathrm{Sn} / \mathrm{Zn} / \mathrm{Cu}$ exhibited an additional $\mathrm{Cu}_{2} \mathrm{~S}$ phase due to $\mathrm{Cu}$ 's position as the top layer. Sulfurization of the other Cu-capped stack, $\mathrm{Zn} / \mathrm{Sn} / \mathrm{Cu}$, resulted in $\mathrm{Cu}_{2} \mathrm{SnS}_{3}$ as a result of $\mathrm{Sn}$ and $\mathrm{Cu}$ being the upper most layers. Moreover, as per the reaction mechanism $\left(\mathrm{Cu}_{2} \mathrm{SnS}_{3}+\mathrm{ZnS} \rightarrow \mathrm{Cu}_{2} \mathrm{ZnSnS}_{4}\right)$ and CZTS phase diagram, the intermediate phases CTS and ZnS are supposed to be formed before the CZTS phase emerges [26]. Hence, in the present stack order, $\mathrm{Zn}$ reaction with CTS is incomplete to form CZTS, since $\mathrm{Zn}$ was at the bottom in the stack $(\mathrm{Zn} / \mathrm{Sn} / \mathrm{Cu})$ that makes it difficult to reach the surface due its low diffusivity resulting in an inadequate quantity of $\mathrm{Zn}$ (in the form of $\mathrm{ZnS}$ ) left a small amount of unreacted CTS remains in the films after sulfurization. To resolve this issue, further study was performed on a new metallic stack under $\mathrm{Cu}$-capped stacks by the addition of a thin $\mathrm{Cu}$ layer $(\sim 65 \mathrm{~nm})$ between the $\mathrm{Zn}$ and $\mathrm{Sn}$ in a $\mathrm{Zn} / \mathrm{Sn} / \mathrm{Cu}$ stack. The total thickness of the $\mathrm{Cu}$ remained the same as in the earlier stacks, however, equally shared for the top layer and middle layer between $\mathrm{Zn}$ and $\mathrm{Sn}$. The stacks with the additional thin $\mathrm{Cu}$ layer did not show any $\mathrm{Cu}$-related secondary phases (i.e. $\mathrm{Cu}_{2-\mathrm{x}} \mathrm{S}$ and $\mathrm{CTS}$ ) 
either in XRD or Raman analysis after sulfurization. The XRD patterns of the sulfurized stack with sequence $\mathrm{Zn} / \mathrm{Cu} / \mathrm{Sn} / \mathrm{Cu}$ showed diffraction planes corresponding to the kesterite CZTS phase. Raman modes at 286 and $336 \mathrm{~cm}^{-1}$ strongly indicate the formation of single phase CZTS. Sulfurization of this stack lead to the clear appearance of a CZTS weak Raman mode at $286 \mathrm{~cm}^{-1}$ and the relative low FWHM of $12 \mathrm{~cm}^{-1}$ (highest intensity) for the strong mode $\left(336 \mathrm{~cm}^{-1}\right)$, indicating a high degree of crystallinity in the films. It is inferred from the analysis that the formation of single phase with good crystallinity is due to the insertion of the additional middle $\mathrm{Cu}$ layer that enables migration of the $\mathrm{Cu}$ atoms towards to the surface, leaving the vacancies during sulfurization. These vacancies provide a path for $\mathrm{Zn}$ atom migration. Moreover according to the Kirkendall effect, the unequal rates of diffusion of $\mathrm{Cu}, \mathrm{Zn}, \mathrm{Sn}$ and $\mathrm{S}$ will help in the initiation of homogeneous mixing and finally yield the CZTS phase [35, 36]. Further, Raman measurements were made at three different places (top, center and bottom) on the film to ensure the single phase growth of CZTS across the specimen (Fig. 4a). Irrespective of the measurement position, the films showed similar Raman modes corresponding to kesterite CZTS. Additionally, Raman mapping was recorded for strong and weak modes over a 60 × $60 \mu \mathrm{m}^{2}$ area (Fig. $4 \mathrm{~b} \& \mathrm{c}$ ). The mapping showed a marginal change in frequency values, i.e. $286-291 \mathrm{~cm}^{-1}$ and $332-338 \mathrm{~cm}^{-1}$ for weak and strong modes, which are close to the reported values [33]. This indicates indicating that the films are highly uniform over the total area. The single phase CZTS films sulfurized from the stack $\mathrm{Zn} / \mathrm{Cu} / \mathrm{Sn} / \mathrm{Cu}$ have exhibited a crystallite size of $105 \mathrm{~nm}$ with lattice constants $\mathrm{a}=$ $5.31 \AA$ and $c=10.63 \AA$. 


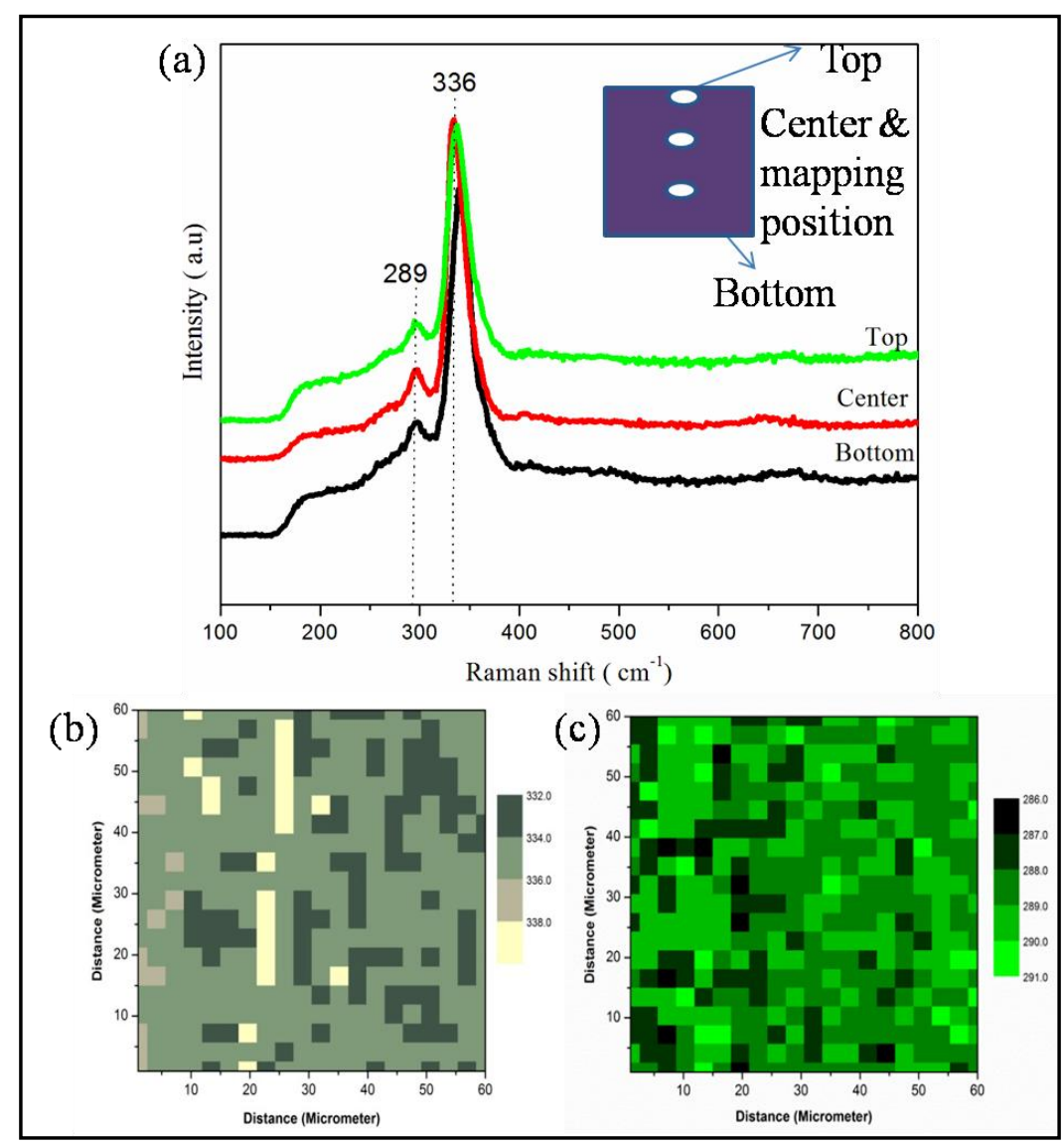

Fig.4 (a) Raman spectra at top, center and bottom for CZTS films sulfurized from $\mathrm{Zn} / \mathrm{Cu} / \mathrm{Sn} / \mathrm{Cu}$ stack and Corresponding Raman Mapping for (b) Strong $\left(\mathrm{A}_{1}\right)$ mode and (c) Weak (E/B) mode. 


\subsection{Microstructure}

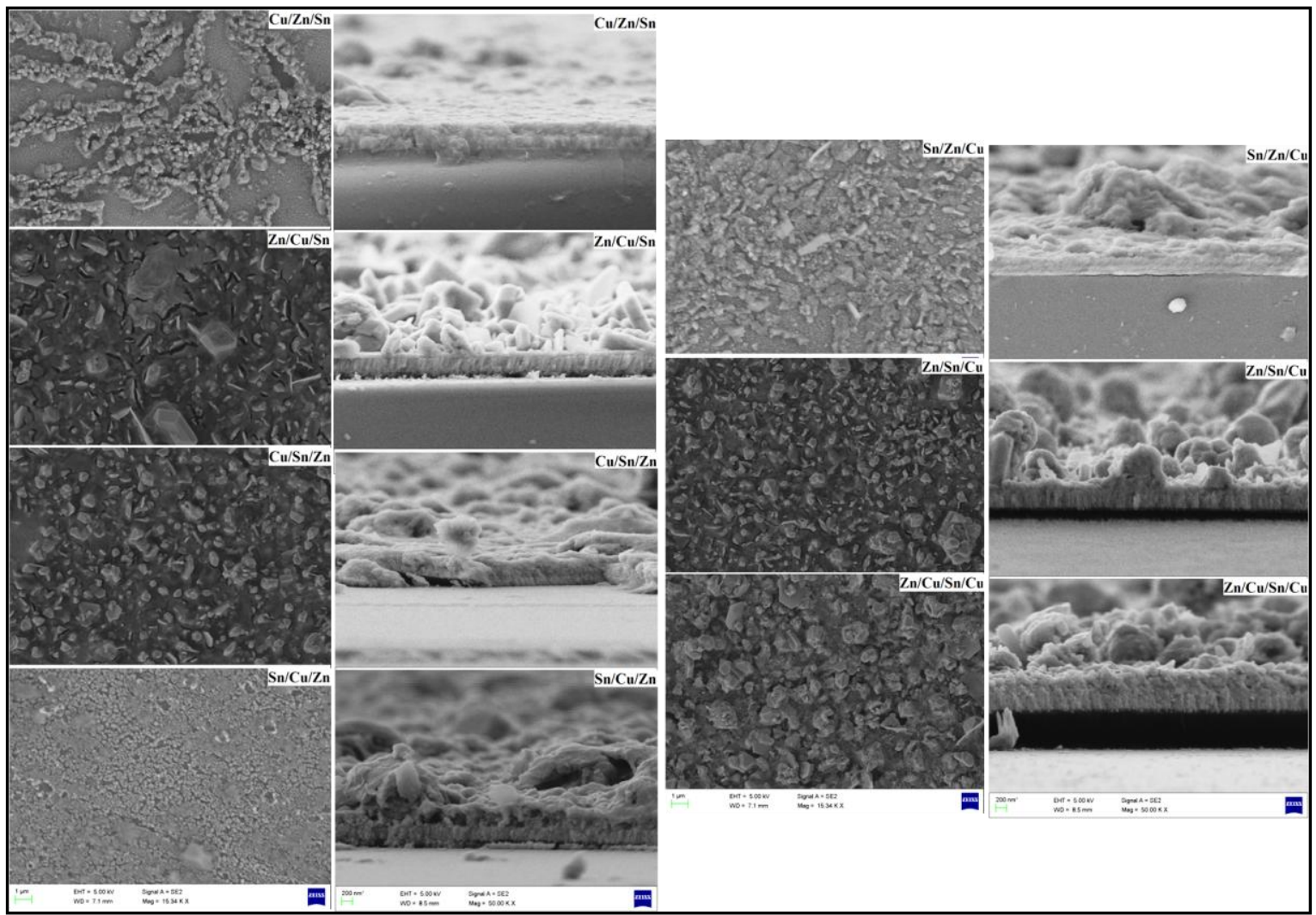

Fig.5. Overhead and cross sectional morphology of the CZTS films prepared from different stack order.

FESEM micrographs showing overhead and cross-sectional views of the CZTS films prepared from different stacking order are shown given in Fig. 5. It is found that the stacking sequence of the precursors significantly affected the surface and cross-sectional morphology of the films due to the considerable changes in compositional ratios. For Sn-capped films, patches and cracks with rough morphology are shown, which could be accounted for by the loss of Sn material in the form of $\mathrm{SnS}_{2}$. A similar type of rough morphology was also observed by previous investigators when Sn precursor was made the capping layer [31, 32, 37]. In general, rough surfaces can increase the absorber/buffer interface area, thereby enhancing carrier recombination and causing a substantial drop in the performance of CZTS-based solar cells. Open circuit voltage is also adversely affected due to probable shunting of the device. For Zn-capped films, cracks on the top surface can be clearly seem due to the loss of volatile $\mathrm{Zn}$, while cross sectional 
view shows fewer voids because of $\mathrm{Cu}$ out-diffusion towards the surface and non-uniform distribution of elements in local micro-regions [38]. Among Cu-capped precursors, the sulfurized stack order $\mathrm{Zn} / \mathrm{Cu} / \mathrm{Sn} / \mathrm{Cu}$ shows closely-packed larger surface grains and very dense bilayer columnar cross-sectional morphology without any voids. The resulting dense cross-sectional morphology indicates single phase growth of CZTS due to homogeneous mixing of all elements. Further, larger grains facilitate larger minority carrier diffusion length and built in potential, which is an important prerequisite for thin film solar cells. The thicknesses measured from the cross-sectional FESEM after sulfurization found to vary in the range, $0.5-0.9 \mu \mathrm{m}$.

\subsection{XPS Analysis}
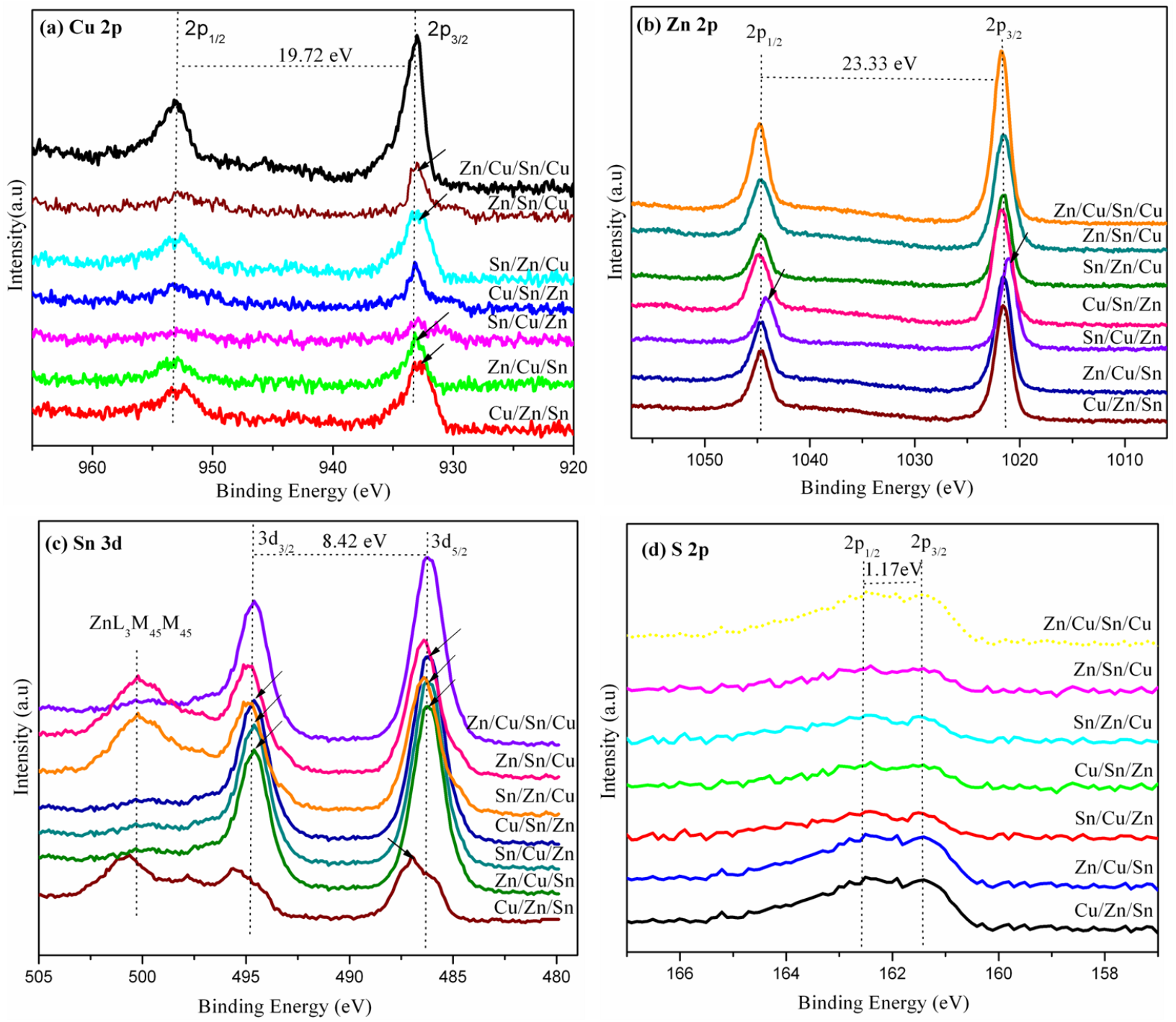

Fig.6. High resolution core level XPS spectra of (a) $\mathrm{Cu} 2 \mathrm{p}$, (b) $\mathrm{Zn} \mathrm{2p}$, (c) Sn 3d and (d) S 2p for all types of stacks. 
XPS was used to determine the oxidation states of the constituent elements in sulfurized metallic stacks. Fig. 6a shows the high resolution XPS spectra of $\mathrm{Cu} 2 \mathrm{p}$ for all sulfurized metallic stack types. The appearance of two sharp peaks at binding energies $933.01 \mathrm{eV}\left(\mathrm{Cu} 2 \mathrm{p}_{3 / 2}\right)$ and $952.73 \mathrm{eV}\left(\mathrm{Cu} 2 \mathrm{p}_{1 / 2}\right)$ with a separation of $19.72 \mathrm{eV}$ indicates the presence of $\mathrm{Cu}^{+1}$ in CZTS based on $\mathrm{Zn} / \mathrm{Cu} / \mathrm{Sn} / \mathrm{Cu}$ [39]. However, the broadening of $\mathrm{Cu} 2 \mathrm{p}_{3 / 2}$ and $\mathrm{Cu} 2 \mathrm{p}_{1 / 2}$ core level peaks in rest of the stacks except $\mathrm{Zn} / \mathrm{Cu} / \mathrm{Sn} / \mathrm{Cu}$ provides further evidence for the presence of other $\mathrm{Cu}$-related phases along with CZTS, as observed in XRD and Raman measurements. The presence of wellresolved doublet $\mathrm{Zn} 2 \mathrm{p}$ peaks at $1022.31\left(\mathrm{Zn} 2 \mathrm{p}_{3 / 2}\right)$ and $1045.64 \mathrm{eV}\left(\mathrm{Zn} 2 \mathrm{p}_{1 / 2}\right)$ with peak splitting of $23.33 \mathrm{eV}$ in all the stack sequences (Fig. 6b) indicates the $\mathrm{Zn}^{+2}$ state in CZTS. On the other hand, a slight shift of $\mathrm{Zn} 2 \mathrm{p}_{3 / 2}$ and $\mathrm{Zn} 2 \mathrm{p}_{1 / 2}$ towards lower binding energy values $(1021.01 \mathrm{eV}$ and $1044.12 \mathrm{eV}$ ) in the case of $\mathrm{Sn} / \mathrm{Cu} / \mathrm{Zn}$ films suggests that $\mathrm{Zn}$ exists in the form of $\mathrm{ZnS}$ [40, 41]. The two $\mathrm{Sn}$ peaks corresponding to $\mathrm{Sn} 3 \mathrm{~d}_{5 / 2}$ and $\mathrm{Sn} 3 \mathrm{~d}_{3 / 2}$ were observed at $486.13 \mathrm{eV}$ and $494.55 \mathrm{eV}$ with a spin-orbit splitting of $8.42 \mathrm{eV}$, revealing the $\mathrm{Sn}^{+4}$ state in CZTS (Fig. 6c) for $\mathrm{Zn} / \mathrm{Cu} / \mathrm{Sn} / \mathrm{Cu}$. However, an extra peak at $487.02 \mathrm{eV}$ along with broadening of the peaks towards higher binding energies (blue shift) was observed for the $\mathrm{Cu} / \mathrm{Zn} / \mathrm{Sn}$ stack after sulfurization, suggesting the existence of a $\mathrm{SnS}_{2}$ phase alongside CZTS [42, 43]. On the other hand, the Sn $3 \mathrm{~d}_{3 / 2}$ and $\mathrm{Sn} 3 \mathrm{~d}_{5 / 2}$ core level peaks of the CZTSs based on the $\mathrm{Zn} / \mathrm{Cu} / \mathrm{Sn}, \mathrm{Cu} / \mathrm{Sn} / \mathrm{Zn}$ and $\mathrm{Sn} / \mathrm{Cu} / \mathrm{Zn}$, show a slight shift towards lower binding energies compared with the CZTSs based on others, indicating the existence of $\mathrm{Sn}$ in other forms of $\mathrm{Cu}_{2} \mathrm{SnS}_{3}$ and/or $\mathrm{SnS}_{2}$ as evidenced from Raman results. In Fig. $6 \mathrm{~d}$ the $\mathrm{S} 2 \mathrm{p}_{3 / 2}$ and $\mathrm{S} 2 \mathrm{p}_{1 / 2}$ peaks are located at 161.41 and $162.58 \mathrm{eV}$ with a separation of $1.17 \mathrm{eV}$, indicating the presence of ionic sulfur. This is consistent with the reported range for sulfide phase, $160-164 \mathrm{eV}[44,45]$.

\subsection{Optical studies}

UV-Vis absorption spectra and a plot of $(\alpha h v)^{2}$ Vs. (hv) for all the sulfurized stacks are presented in Fig. 7. The absorption coefficient was calculated using the relation [19],

$$
\alpha=\frac{2.303 A}{t}
$$

where $\mathrm{A}$ is absorbance, $\mathrm{t}$ is thickness of the film and $\alpha$ is the absorption coefficient. 

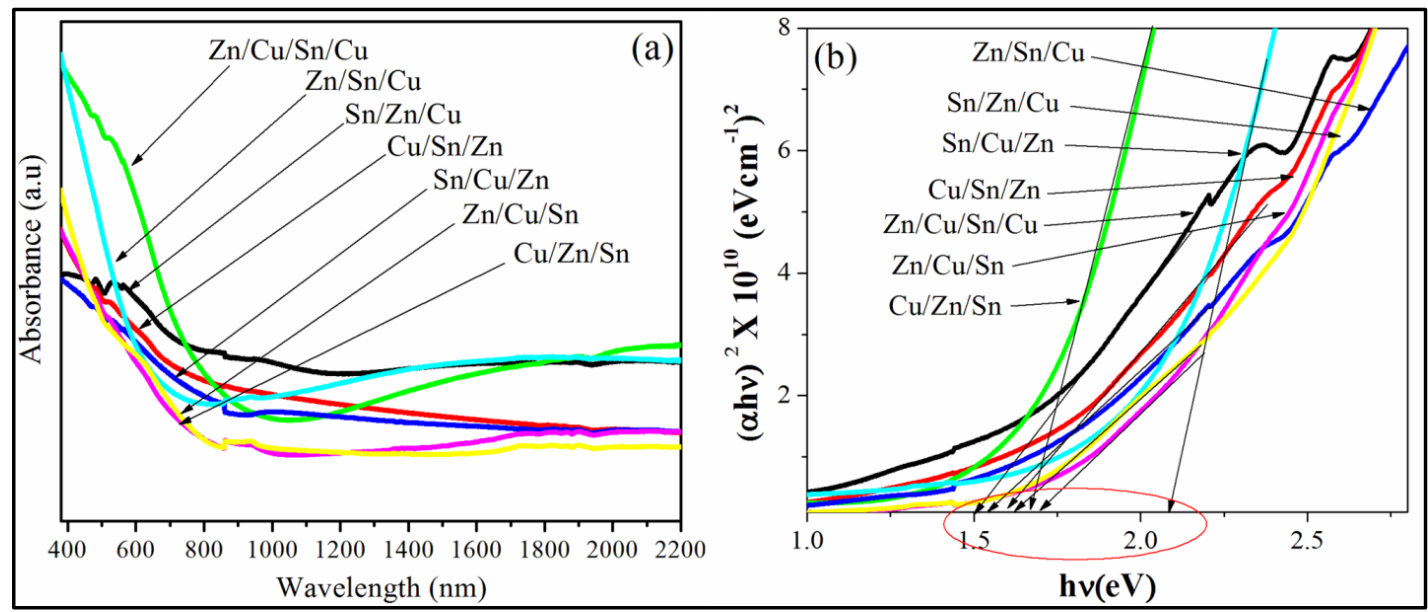

Fig.7 (a) Absorbance and (b) the plot of $(\alpha h v)^{2}$ Vs. photon energy of stacks after sulfurization.

It is observed that all the sulfurized stacking sequences showed a sudden rise in absorbance near visible region with an absorption coefficient $>10^{5} \mathrm{~cm}^{-1}$, indicating a direct band gap nature [46]. The optical band gap of the sulfurized films was measured by extrapolating the linear part of the $(\alpha h v)^{2}$ Vs. (hv) plot on to the hv axis. The measured optical band gaps for the stack orders $\mathrm{Cu} / \mathrm{Zn} / \mathrm{Sn}, \mathrm{Zn} / \mathrm{Cu} / \mathrm{Sn}, \mathrm{Sn} / \mathrm{Cu} / \mathrm{Zn}, \mathrm{Cu} / \mathrm{Sn} / \mathrm{Zn}, \mathrm{Sn} / \mathrm{Zn} / \mathrm{Cu}, \mathrm{Zn} / \mathrm{Sn} / \mathrm{Cu}$ and $\mathrm{Zn} / \mathrm{Cu} / \mathrm{Sn} / \mathrm{Cu}$ were $1.7,1.68,2.1,1.65,1.63,1.65$ and $1.52 \mathrm{eV}$, respectively. The presence of wider band gap energies in all the stack orders except $\mathrm{Zn} / \mathrm{Cu} / \mathrm{Sn} / \mathrm{Cu}$ was attributed to the secondary phases $\mathrm{Cu}_{2-}$ ${ }_{x} \mathrm{~S}, \mathrm{SnS}_{2}$ and $\mathrm{Cu}_{2} \mathrm{SnS}_{3}$ alongside CZTS. Besides, the particular stack order $\mathrm{Zn} / \mathrm{Cu} / \mathrm{Sn} / \mathrm{Cu}$ exhibited a band gap energy of $1.52 \mathrm{eV}$, which is in good agreement with the reported values for CZTS.

\subsection{Electrical studies}

The type of carriers and electrical properties of the sulfurized stacks were determined using hot probe test and four probe Hall effect set-up, respectively. The sulfurized films were ptype in nature. Table 2 shows the sheet resistance, carrier concentration and hole mobility for all stacking types after sulfurization. Of the sulfurized metallic stacks, $\mathrm{Zn} / \mathrm{Cu} / \mathrm{Sn} / \mathrm{Cu}$ exhibited highest mobility at $22.9 \mathrm{~cm}^{2} / \mathrm{V}$-s, with a carrier concentration of $6.8 \times 10^{17} \mathrm{~cm}^{-3}$. While the rest of the sulfurized stacks showed higher carrier concentration in the order of $10^{18}-10^{19} \mathrm{~cm}^{-3}$, close to effective density of states due to semi-metallic behavior on account of $\mathrm{Cu}$ related phases (mainly $\mathrm{Cu}_{2-\mathrm{x}} \mathrm{S}$ ), and thereby thus resulting in decrease of carrier mobility [47, 48]. The decrease of 
mobility in all other sulfurized stacks (except $\mathrm{Zn} / \mathrm{Cu} / \mathrm{Sn} / \mathrm{Cu}$ ) can also be accounted for by morphological problems like cracks, voids and small grain size as seen in FESEM images.

Table 2. Electrical parameters of CZTS films prepared from different stack order.

\begin{tabular}{|l|l|l|l|}
\hline Stack order & $\begin{array}{l}\text { Sheet Resistance } \\
(\Omega / \text { sq. })\end{array}$ & $\begin{array}{l}\text { Hole concentration } \\
\left(\mathrm{cm}^{-3}\right)\end{array}$ & $\begin{array}{l}\text { Mobility } \\
\left(\mathrm{cm}^{2} / \mathrm{V}-\mathrm{s}\right)\end{array}$ \\
\hline $\mathrm{Cu} / \mathrm{Zn} / \mathrm{Sn}$ & $1.04 \times 10^{5}$ & $6.2 \times 10^{18}$ & 0.1 \\
\hline $\mathrm{Zn} / \mathrm{Cu} / \mathrm{Sn}$ & $5.4 \times 10^{5}$ & $2.3 \times 10^{19}$ & 0.1 \\
\hline $\mathrm{Sn} / \mathrm{Cu} / \mathrm{Zn}$ & $1.25 \times 10^{5}$ & $1.2 \times 10^{17}$ & 5.2 \\
\hline $\mathrm{Cu} / \mathrm{Sn} / \mathrm{Zn}$ & $2.28 \times 10^{4}$ & $1.0 \times 10^{18}$ & 3.9 \\
\hline $\mathrm{Sn} / \mathrm{Zn} / \mathrm{Cu}$ & $3.0 \times 10^{4}$ & $1.8 \times 10^{18}$ & 1.1 \\
\hline $\mathrm{Zn} / \mathrm{Sn} / \mathrm{Cu}$ & $1.2 \times 10^{4}$ & $5.4 \times 10^{17}$ & 9.6 \\
\hline $\mathrm{Zn} / \mathrm{Cu} / \mathrm{Sn} / \mathrm{Cu}$ & $4.0 \times 10^{3}$ & $6.8 \times 10^{17}$ & 22.9 \\
\hline
\end{tabular}

\section{Conclusion}

In summary, seven different kinds of metallic stacking orders, categorized into Sncapped, $\mathrm{Zn}$-capped and $\mathrm{Cu}$-capped based on the top metallic layer, were examined to understand the influence of metallic stacking order during high temperature sulfurization $\left(\mathrm{T}_{\mathrm{s}}=500{ }^{\circ} \mathrm{C}\right)$ on the growth of CZTS thin films. Drastic changes in the metallic composition ratios and morphologies were noticed for Sn-capped and Zn-capped stacks after sulfurization. Among the $\mathrm{Cu}$-capped stacks, the post sulfurization of a particular stacking order, $\mathrm{Zn} / \mathrm{Cu} / \mathrm{Sn} / \mathrm{Cu}$, resulted in similar metallic ratios as to that of un-sulfurized stacks and with denser columnar morphology. The combination of XRD and Raman studies revealed that the CZTS films obtained by sulfurization of the above stack had very strong kesterite phase of CZTS with corresponding Raman modes occurring at $336 \mathrm{~cm}^{-1}$ and $286 \mathrm{~cm}^{-1}$. The XPS study confirmed the oxidation states, $\mathrm{Cu}^{+1}, \mathrm{Zn}^{+2}, \mathrm{Sn}^{+4}$ and $\mathrm{S}^{-2}$ in the CZTS films based on $\mathrm{Zn} / \mathrm{Cu} / \mathrm{Sn} / \mathrm{Cu}$. These films had an optical band gap of $1.52 \mathrm{eV}$ with electrical mobility of $\sim 22.9 \mathrm{~cm}^{2} / \mathrm{V}$-s. The perfect single phase growth is an important step towards the realization of high efficiency CZTS solar cells. 


\section{Acknowledgements}

One of the authors, Y.P.V.S. thanks University Grants Commission of the Government of India for providing support under the Indo-US Raman post-doctoral fellowship scheme. Research at University of Utah was supported by the National Science Foundation through Grant Nos. 1121252 (MRSEC) and 1407650.

\section{References}

[1] T. Ameri, N. L. Christoph, J. Brabec, Highly efficient organic tandem solar cells: a follow up review, Energy Environ. Sci., 6 (2013) 2390-2413.

[2] A. Qiaoshi , F. Zhang, J. Zhang, W. Tang, Z. Deng, B. Hu, Versatile ternary organic solar cells: a critical review, Energy Environ. Sci., 00 (2015) 1-42. (DOI: 10.1039/C5EE02641E)

[3] J. You, L. Dou, Z. Hong, G. Li, Y. Yang, Recent trends in polymer tandem solar cells, Prog. Polymer Sci., 38 (2013) 1909-1928.

[4] M. Vasilopoulou, A. M. Douvas, L. C. Palilis, S. Kennou, P. Argitis, Old Metal Oxide Clusters in New Applications: Spontaneous Reduction of Keggin and Dawson Polyoxometalate Layers by a Mettalic Electrode for Improving Efficiency in Organic Optoelectronics, J. Am. Chem. Soc., 137 (2015) 6844-6856.

[5] D. Wang, M. Wright, E. Naveen Kumar, A. Uddin, Stability of perovskite solar cells, Sol. Energy Mater. Sol. Cells, 147 (2016) 255-275.

[6] J. Jean, P. R. Brown, R. L. Jaffe, T. Buonassisi, V. Bulovi', Pathways for solar photovoltaics, Energy Environ. Sci., 00 (2015) 1-40. (DOI: 10.1039/c4ee04073b).

[7] M.A. Green, K. Emery, Y. Hishikawa, W. Warta and E.D. Dunlop, Solar efficiency tables (Version 43), Prog. Photovoltaics, 24 (2014) 1-9.

[8] D. B. Mitzi, O. Gunawan, T. K. Todorov, D. A. R. Barkhouse, Prospects and performance limitations for $\mathrm{Cu}-\mathrm{Zn}-\mathrm{Sn}-\mathrm{S}-\mathrm{Se}$ photovoltaic technology, Phil. Trans. R. Soc., A 371 (2013) 20110432(1-22).

[9] H. Katagiri, K. Jimbo, W. I.N. S. Maw, K. Oishi, M. Yamazaki, H. Araki, A. Takeuchi, Development of CZTS- based thin film solar cells, Thin Solid Films, 517 (2009) 2455-2460.

[10] B. Shin, O. Gunawan, Y. Zhu, N. A. Bojarczuk, S. J. Chey, S. Guha, Thin film solar cell with $8.4 \%$ power conversion efficiency using an earth-abundant $\mathrm{Cu}_{2} \mathrm{ZnSnS}_{4}$ absorber, Prog. Photovoltaics, 21 (2013) 72-76. 
[11] H. Katagiri, K. Jimbo, M. Tahara, H. Araki and K. Oishi, The influence of the composition ratio on CZTS-based thin film solar cells, Mater. Res. Soc. Symp. Proc., 1165 (2009) M 0401 .

[12] H. Hiroi, N. Sakai, T. Kato, H. Sugimoto, In High Voltage $\mathrm{Cu}_{2} \mathrm{ZnSnS}_{4}$ Submodules by Hybrid Buffer Layer, Photovoltaic Specialists Conference (PVSC), 2013 IEEE 39th, Tampa, FL. 16-21 June 2013; Tampa, FL, (2013) 0863-0866.

[13] H. Sugimoto, C. Liao, H. Hiroi, N. Sakai, T. Kato, In Lifetime Improvement for High Efficiency $\mathrm{Cu}_{2} \mathrm{ZnSnS}_{4}$ Submodules, Photovoltaic Specialists Conference (PVSC), 2013 IEEE 39th, Tampa, FL. 16-21 June 2013; Tampa, FL, 00 (2013) 3208-3211.

[14] W. Shockley, H. J. Queisser, Detailed Balance Limit of Efficiency of p-n Junction Solar Cells, J. of Appl. Phys., 32 (1961) 510-519.

[15] F. Jiang, H. Shen, Research on the photoresponse current and photosensitive properties of $\mathrm{Cu}_{2} \mathrm{ZnSnS}_{4}$ thin film prepared by sulfurization of a sputtered metal precursor, $R S C A d v ., 3$ (2013) 23474-23481.

[16] T. Tanaka, D. Kawasaki, M. Nishio, Q. Guo, H. Ogawa, Fabrication of $\mathrm{Cu}_{2} \mathrm{ZnSnS}_{4}$ thin films by co-evaporation, Phys. Status Solidi C, 3(2006) 2844-2847.

[17] K. Moriya, K. Tanaka, H. Uchiki, Fabrication of $\mathrm{Cu}_{2} \mathrm{ZnSnS}_{4}$ thin-film solar cell prepared by pulsed laser deposition, Jpn. J. Appl. Phys.,46 (2007) 5780-5781.

[18] J. J.Scragg, P. J. Dale, L. M. Peter, G. Zoppi, I.A. N. Forbes, New routes to sustainable photovoltaics: evaluation of $\mathrm{Cu}_{2} \mathrm{ZnSnS}_{4}$ as an alternative absorber material, Phys. Status Solidi B, 245 (2008) 1772-1778.

[19] C. $\mathrm{Mu}$, Y. Song, A. Liu, X. Wang, J. Hu, H. Ji, H. Zhang, Electrospun $\mathrm{Cu}_{2} \mathrm{ZnSnS}_{4}$ microfibers with strong (112) preferred orientation: fabrication and Characterization, $R S C$ $A d v ., 5$ (2015) 15749-15755.

[20] K. Kornhuber, J. Kavalakkatt, X. Lin, A. Ennaoui, M. Ch.Lux-Steiner, In situ monitoring of electrophoretic deposition of $\mathrm{Cu}_{2} \mathrm{ZnSnS}_{4}$ nanocrystals, RSC Adv.3(2013) 5845-5850.

[21] S. Marchionna, P. Garattini, A. Le Donne, M. Acciarri, S. Tombolato, S. Binetti, $\mathrm{Cu}_{2} \mathrm{ZnSnS}_{4}$ solar cells grown by sulphurisation of sputtered metal precursors, Thin Solid Films , 542 (2013)114-118.

[22] S. Siebentritt, Why are kesterite solar cells not 20\% efficient?, Thin Solid Films, 535 (2013) $1-4$.

[23] A. Weber, R. Mainz, H.W. Schock, On the Sn loss from thin films of the material system Cu-Zn-Sn-S in high vacuum. J. Appl. Phys., 107 (2010) 013516-1-013516-6. 
[24] A. Weber, H. Krauth, S. Perlt, B. Schubert, I. Kotschau, S. Schorr, H.W. Schock, Multistage evaporation of $\mathrm{Cu}_{2} \mathrm{ZnSnS}_{4}$ thin films. Thin Solid Films, 517 (2009) 2524- 2526.

[25] T. Narayana , Y. P. V. Subbaiah , P. Prathap , Y. B. K. Reddy , K. T. R. K. Reddy, Influence of sulfurization temperature on physical properties of $\mathrm{Cu}_{2} \mathrm{ZnSnS}_{4}$ thin films, $J$. Renewable and sustainable energy, 5 (2013) 031606-1-031606-7.

[26] Narayana Thota, Y. P. V. Subbaiah , P. Prathap , Y. B. K. Reddy , G. H Chandra, Two step growth mechanism of $\mathrm{Cu}_{2} \mathrm{ZnSnS}_{4}$ thin films, Physica B, 449 (2014) 255-260.

[27] J. J. Scragg, T. Ericson, T. Kubart, M. Kdoff and C. P. Bjorkman, Chemical insights into the instability of $\mathrm{Cu}_{2} \mathrm{ZnS}_{4}$ films during annealing, Chem. Mater., 23 (2011) 4625-4633.

[28] C. B. Alcock, V.P. Itkin, M.K. Horrigan, Vapour Pressure Equations for the Metallic Elements: 298-2500K. Can. Metall. Q, 23 (1984) 309-313.

[29] A. Fairbrother, L. Fourdrinier, X. Fontane, V. Izquiero-Roca, M. Dimitrievska, A. PerezRodriguez, E. Saucedo, Precursor stack ordering Effects in $\mathrm{Cu}_{2} \mathrm{ZnSnSe}_{4}$ thin films prepared by Rapid thermal processing; J. Phys. Chem. C, 118 (2014) 17291-17298.

[30] M. Perret, N. A. Stolwijk, L. Cohausz, Kick-Out diffusion of Znic in silicon at 1262K, J. Phys.: Condensed Matter,1 (1986) 6347-6361.

[31] E. M. Mkawi, K. Ibrahim, M. K. M. Ali, M. A. Farrukh, N. K. Allam, Influence of precursor thin film s stacking order on the properties of $\mathrm{Cu}_{2} \mathrm{ZnSnS}_{4}$ thin films fabricated by electrochemical deposition method, Superlattices and Microstructures, 76 (2014)339-348.

[32] D. H. Son, D. H. Kim, K. J. Yang, D. Nam, M. Gansukh, H. Cheong, J. K. Kang, Influence of precursor sulfur content on film formation and the properties of sulfurized $\mathrm{Cu}_{2} \mathrm{ZnSnS}_{4}$ thin films for solar cells, Phys. Status Solidi A, 211 (2014) 946-951.

[33] P.A. Fernandes, P.M.P. Salomé, A.F. da Cunha, Study of polycrystalline $\mathrm{Cu}_{2} \mathrm{ZnSnS}_{4}$ films by Raman scattering, J. Alloys Com.,509 (2011) 7600-7606.

[34] W. G. Nilsen, Raman Spectrum of Cubic ZnS, Phys. Rev., 182 (1969) 838-850.

[35] X. Fontané, L. Calvo-Barrio, V. Izquierdo-Roca, E. Saucedo, A. Pérez-Rodríguez, J. R. Morante, D. M. Berg, P. J. Dale, and S. Siebentritt, In- depth resolved Raman scattering analysis for identification of secondary phases: characterization of $\mathrm{Cu}_{2} \mathrm{ZnSnS}$ layers for solar cell application, Appl. Phys. Lett., 98 (2011) 181905-1 -181905-3.

[36] X. Liu, M.T. Mayer,D. Wang, Understanding ionic vacancy diffusion growth of cuprous sulfide nanowires, Angew. Chem. int.Ed., 49 (2010) 3165-3168. 
[37] H. Araki , A Mikaduki, Y. Kubo, T. Sato, K. Jimbo, W. S. Maw, H. Katagiri, M. Yamazaki, K. Oishi, A. Takeuchi, Preparation of $\mathrm{Cu}_{2} \mathrm{ZnSnS}_{4}$ thin films by sulfurization of stacked metallic layers, Thin Solid Films, 517 (2008) 1457-1460.

[38] H. Yoo, J.H. Kim, Comparative study of $\mathrm{Cu}_{2} \mathrm{ZnSnS}_{4}$ film growth, Sol. Energy Mater. Sol. Cells, 95 (2011)239-244.

[39] M. P. Suryawanshi, S. W. Shin, U. V. Ghorpade, K. V. Gurva, C. W. Hong, G. L. Agawane, S. A. Vanalakar, J. H. Moon, J. H. Yun, P. S. Patil, J. H. Kim, A. V. Moholkar, Improved photoelectrochemical performance of $\mathrm{Cu}_{2} \mathrm{ZnSnS}_{4}$ (CZTS) thin films prepared using modified successive ionic layer adsorption and reaction (SILAR) sequence, ElectrochimicaActa, 150 (2014) 136-145.

[40] D.S. Kim, Y.J. Cho, J. Park, J. Yoon, Y. Jo, M. H. Jung,(Mn, Zn) Co-doped CdS nano wires, J. Phys. Chem. C, 111 (2007) 10861-10868.

[41] W. Liu, B. Guo, C. Mak, A. Li, X. Wu, F. Zhang, Facile synthesis of ultrafine $\mathrm{Cu}_{2} \mathrm{ZnSnS}_{4}$ nanocrystals by hydrothermal method for use in solar cells, Thin solid films, 535 (2013) 3943.

[42] C. Khelia, K. Boubaker, T.B. Nasrallah, M. Amlouk, S. Belgacem, Morphological and Thermal properties of $\beta-\mathrm{SnS}_{2}$ sprayed thin films using Boubaker polynomials expansion, $J$. Alloys Compd., 477 (2009) 461-467.

[43] S. W. Shin, S. M. Pawar, C. Y. Park , J. H. Yun, J. H. Moon, J. H. Kim , J. Y. Lee, Studies on $\mathrm{Cu}_{2} \mathrm{ZnSnS}_{4}$ (CZTS) absorber layer using different stacking orders in precursor thin films, Sol. Energy Mater. Sol. Cells, 95 (2011) 3202- 3206.

[44] P. An, Z. Liang, X. Xu, X. Wang, H. Jin, N. Wang, J. Wang, F. Zhu, A heating-up method for the synthesis of pure phase kesterite $\mathrm{Cu}_{2} \mathrm{ZnSnS}_{4}$ nanocrystals using a simple coordinating sulphur precursor, $R S C A d v$., 5 (2015) 6879-6885.

[45] G. Gordillo, C. Calderon, P. Bartolo-Perez: XPS analysis and structural and morphological characterization of $\mathrm{Cu}_{2} \mathrm{ZnSnS}_{4}$ thin films grown by sequential evaporation, Appl. Sur. Sci., 305 (2014) 506-514.

[46] J. I. Pankove, Optical Process in Semiconductor (Dover Inc., New York, 1975), (1975) 93.

[47] Th.M. Friedlmeier, N. Wieser, Th. Walter, H. Dittrich, H.W. Schock, Heterojunctions based on $\mathrm{Cu}_{2} \mathrm{ZnSnS}_{4}$ and $\mathrm{Cu}_{2} \mathrm{ZnSnSe}_{4}$ thin films, Proceedings of the 14th European PVSEC and Exhibition, 00 (1997) 10.

[48] E. Anastassakis, Light scattering in transition metal diselenides $\mathrm{CoSe}_{2}$ and $\mathrm{CuSe}_{2}$, Solid State Comm.,13 (1973) 1297-1301. 


\section{Table of Contents Graphic}

\begin{tabular}{|c|}
\hline $\mathrm{Cu}$ \\
\hline $\mathrm{Sn}$ \\
\hline $\mathrm{Cu}$ \\
\hline $\mathrm{Zn}$ \\
\hline Glass \\
\hline
\end{tabular}

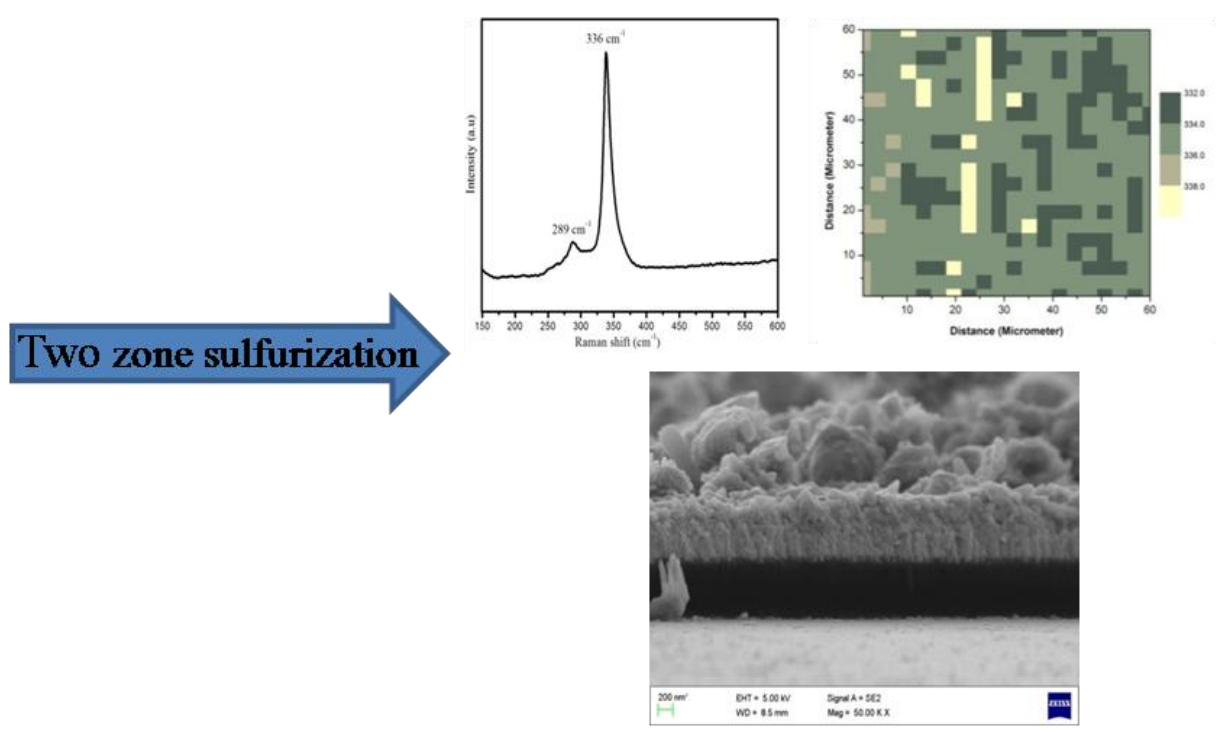

